\begin{tabular}{|l|l|l|}
\hline \multicolumn{2}{|c|}{ PublisherInfo } \\
\hline \hline PublisherName & $:$ & Palgrave Macmillan UK \\
\hline \hline PublisherLocation & $:$ & London \\
\hline \hline PublisherImprintName & $:$ & Palgrave Macmillan \\
\hline
\end{tabular}

\title{
Regional economic indicators November 2007 with a focus on rural and urban differences in the English regions
}

\begin{tabular}{||l|l|l||}
\hline \multicolumn{2}{|c|}{ ArticleInfo } \\
\hline \hline ArticleDOI & $:$ & 10.1057 /palgrave.elmr.1410173 \\
\hline \hline ArticleCategory & $:$ & Feature \\
\hline \hline ArticleFirstPage & $:$ & 48 \\
\hline \hline ArticleLastPage & $:$ & 58 \\
\hline \hline & $:$ & $\begin{array}{l}\text { RegistrationDate }: 2007-11-16 \\
\text { ArticleHistory }\end{array}$ \\
& $:$ OnlineDate $\quad$ 2007-11-16 \\
\hline \hline ArticleCopyright & $:$ & Crown copyright2007 \\
\hline \hline
\end{tabular}


Claire Swadkin, ${ }^{\text {Aff1 }}$

Barbara Louca, ${ }^{\text {Aff1 }}$

Dev Virdee, ${ }^{\text {Aff1 }}$

\section{Compiles information covering the nine English Government Office Regions, Northern Ireland, Scotland and Wales for the above.}

This quarter, regional economic indicators (REI) focuses on patterns of rural and urban differences in the English regions. Data on benefit claimant counts, education attainment and the Index of Multiple Deprivation are analysed using the rural and urban classification. This is followed by the regular Headline Indicators which cover the nine Government Office Regions of England, Northern Ireland, Scotland and Wales. These 12 areas comprise level 1 of the European Nomenclature of Units for Territorial Statistics (NUTS) for the UK. The term 'region' is used for convenience in this article. The headline indicators present an underlying picture of regional economic performance, productivity (including an update to 2005 of the productivity analysis published in the February article) and welfare. Labour market data and indicators of the main drivers of productivity are also included.

Misc

The Full Text of this article can be found on the National Statistics website (http://www.statistics.gov.uk/elmr/11_07/downloads/elmr_nov07_swadkin.pdf). 